\title{
Agrowisata Hortikultura Dengan Pendekatan Kearifan lokal Di TAWANGMANGU KABUPATEN KARANGANYAR
}

\author{
Angga Catur Romadhon, Widi Suroto, Tri Yuni Iswati \\ Program Studi Arsitektur \\ Universitas Sebelas Maret Surakarta \\ Email: anggacaturramadhan77@gmail.com
}

\begin{abstract}
Tawangmangu horticulture agrotourism is more specific agro present for agro tourism which includes fruits, vegetables, ornamental plants, and medicinal plants that have been cultivated and developed in the Tawangmangu. Agro horticulture design by many potential and prospects for development of agro tourism in Tawangmangu, and the number of outstanding issues which states that the existence of an agro tourism will damage and affect the balance of nature that result in natural disasters, such as flooding, erosion (landslides), and global warming. This happens due to the lack of principles of local wisdom that underlie the surrounding communities in the preservation of the environment are becoming increasingly eroded and disappeared. In the planning concept and its design, Agro horticulture uses the concept of local wisdom approach as the basis of planning and design which emphasizes environmental conservation and cropping patterns communities around the site right as part of the concept of local knowledge on which the architectural approach of the Agro Horticulture Tawangmangu. The problem is how to plan and design Agro horticulture educational and recreational as well as local wisdom characterized agro tourism. The method used is the technique of collecting data and analyzing them through the principles of local knowledge as an architectural approach. With the Agro horticulture of the local wisdom, is expected to produce an Agro Horticulture as a recreational vessel agro tourism and educational that can accommodate various types of tourist activities.
\end{abstract}

Keywords: Agro Horticulture, Local Wisdom, Environmental Conservation, recreational, educative.

\section{PENDAHULUAN}

Agrowisata Holtikultura adalah suatu kegiatan wisata agro yang di mana meliputi tanaman buah, sayur, tanaman hias, dan tanaman obat sebagai tujuan wisatanya. Kegiatan wisata agro (agrowisata) itu sendiri adalah suatu bentuk kegiatan wisata yang semakin popular di kalangan masyarakat luas

Agrowisata Holtikultura di Tawangmangu ini direncanakan sebagai wadah wisata agro yang beredukasi serta tidak meningalkan pengertian pokok dari agrowisata yang mencakup atas tanam-petik-jual yang disuguhkan. Oleh karena itu diperlukan pendekatan arsitektural yang dapat menapung segala kegiatan yang mencerminkan kondisi asli dari daerah yang menjadi lokus dari target perencanaan dan perancangan Agroisata Holtikultura tersebut.

Tidak hanya itu konsep pendekatan kearifan lokal yang digunakan sebagai landasan dari proses perencanaan dan perancangan
Agrowisata Holtikultura akan menghasilkan suatu rancang bangun Agrowisata Holtikultura yang mempunyai kondisi tapak yang alami, menjaga keselarasan alam (konservasi lingkungan), menjadikan lingkungan yang semakin memperhatikan keindahan alaminya yang membuat para wisatawan merasakan akan suasana dan keindahan yang alami serta menjadikan suatu agrowisata yang berkearifan lokal.

\section{METODE}

Pengumpulan data dan permasalahan dimulai dari adanya berbagai potensi dan prospek wisata agro, adanya berbagai isu tentang adanya suatu agrowisata, dan kurangnya prinsipprinsip kearifan lokal masyarakat setempat di dalam menjaga keseimbangan alam di daerah Tawangmangu. Setelah permasalahan didapat, dilakukan analisis perencanaan dan perancangan yaitu mengidentifikasi permasalahan yang ada berdasarkan konsep desain. Permasalahan pada 
perencanaan dan perancangan Agrowisata Holtikultura Tawangmangu diselesaikan dengan pendekatan arsitektural kearifan lokal.

Pendekatan kearifan lokal yang diterapkan banyak mengadopsi dari prinsipprinsip kearifan lokal itu sendiri, sehingga dalam proses rancang bangun Agrowisata Holtikultura Tawangmangu tidak berdampak pada tapak sekitar, serta meningkatkan konservasi lingkungan sekitar tapak. Prinsip-prinsip kearifan lokal tersebut adalah sebagai berikut;

1. Tata kelola.

2. Nilai-nilai adat.

3. Pemilihan tempat dan ruang.

4. Tata cara dan prosedur.

5. Konservasi lingkungan.

6. Sesuai tapak sekitar.

7. Sesuai dengan iklim sekitar. (Pitana,2011)

Kearifan lokal menjadi landasan dan batasan di dalam merancang Agrowisata Holtikultura Tawangmangu, seperti pemilihan material bangunan, material lansekap, meningkatkakan daerah konservasi lingkungan, serta memperluas daerah peresapan, sehingga dengan adanya Agrowisata holtikultura tersebut tidak memiliki dampak buruk bagi lingkungan sekitar tapak.

Analisis perencanaan yang dilakukan dengan mengolah data yang telah terkumpuldan dikelompokkan berdasarkan,

1. Pemrograman fungsional dilakukan untuk menentukan pengguna dan kegiatan yang diwadahi di Agrowisata Holtikultura. Dari tahapan ini pengguna dan alur kegiatan secara skematik diidentifikasi sehingga memperoleh konsep kegiatan dan kegiatan sesuai perencanaan objek yang diambil.

2. Pemrograman performansi merupakan pendekatan sistem fungsi dari wadah arsitektural sehingga ditemukan persyaratan karakteristik respon desain. Analisa ini juga berkaitan dengan kebutuhan ruang serta kegiatan pelaku agrowisata.

3. Pemrograman artapakktur merupakan penerjemahan analisis berdasarkan efektifitas fungsi dan persyaratan performansi secara arsitektural ke dalam spesifikasi kawasan dan bangunan Agrowisata Tawangmangu yang akan dirancang, dengan kata lain pada tahap ini dilakukan untuk memperoleh desain ideal. Analisa ini diantaranya berupa program bentuk, program ruang, program tapak, dan program struktur dan utilitas yang berkearifan lokal.

\section{ANALISIS}

\subsection{Analisis Ruang}

Analisis peruangan ini bertujuan guna mendapatkan kebutuhan ruang dari berbagai jenis kegiatan yang akan diwadahi di dalam Agrowisata Holtikultura Tawangmangu. Agrowisata Holtikultura Tawangmangu membutuhkan peruangan yang dapat menampung pola kegiatan dasar agrowisata itu sendiri, yaitu pola kegiatan tanam-petik-jual (lihat Tabel 1. Kebutuhan Ruang)

Tabel 1.Kebutuhan Ruang

\begin{tabular}{|c|c|c|}
\hline${ }_{\text {ELAKU }}{ }^{P}$ & $\begin{array}{r}\mathrm{K} \\
\text { EGIATAN }\end{array}$ & ${ }_{\text {ANGAN }}$ PERU \\
\hline \multirow[t]{11}{*}{$\begin{array}{r}P \\
\text { engunjung }\end{array}$} & $\begin{array}{ll}\text { Da } \\
\text { tang }\end{array}$ & ${ }_{\text {Penerima }}^{\text {Aula }}$ \\
\hline & \multirow[t]{4}{*}{ ukasi } & $\begin{array}{ll} & \text { Green } \\
\text { House } & \end{array}$ \\
\hline & & $\begin{array}{ll} & \text { Perpus } \\
\text { takan } & \end{array}$ \\
\hline & & $\begin{array}{l}\text { Aula } \\
\text { in \& outdoor }\end{array}$ \\
\hline & & $\begin{array}{l}\text { Kebun } \\
\text { Holtikultura }\end{array}$ \\
\hline & \multirow[t]{6}{*}{ isata } & $\begin{array}{ll} & \text { Kebun } \\
\text { Buah } & \end{array}$ \\
\hline & & $\begin{array}{ll} & \text { Kebun } \\
\text { Sayur } & \end{array}$ \\
\hline & & $\begin{array}{l}\text { Kebun } \\
\text { Tanaman Hias }\end{array}$ \\
\hline & & $\begin{array}{l}\text { Kebun } \\
\text { Tanaman Obat }\end{array}$ \\
\hline & & nd $\quad$ Outbo \\
\hline & & $\begin{array}{ll} & \text { SPA } \\
\text { centre } & \end{array}$ \\
\hline \multirow[t]{3}{*}{${ }_{\text {engelola }}$ P } & $\operatorname{tang}$ & $\begin{array}{l}\text { Gedun } \\
\text { g Pengelola }\end{array}$ \\
\hline & rawatan $P$ & $\begin{array}{l}\text { Gedun } \\
\text { g Perawatan }\end{array}$ \\
\hline & $\begin{array}{ll}\text { rcocok } & \mathrm{Be} \\
\text { Tanam } & \end{array}$ & $\begin{array}{l}\text { Kebun } \\
\text { Holtikultura }\end{array}$ \\
\hline
\end{tabular}




\subsection{Analisis Lokasi}

Dalam perencanaan dan perancangan Agrowisata Holtikultura di Tawangmangu sebagai objek wisata yang berkearifan lokal harus mempertimbangkan hal-hal sebagai berikut ini:

1. Sesuai dengan RUTRK Kabupaten Karanganyar.

2. Orientasi ke arah pegunungan yang menarik, sehingga pengunjung dapat menikmati view dari dalam dan luar tapak atau objek wisata (agrowisata) yang direncanakan.

3. Perencanaan objek wisata yang berkearifan lokal sesuai dengan prinsip kearifan lokal setempat (Tawangmangu).

4. Akses transportasi umum mudah, sehingga pencapaian ke lokasi tidak sulit.

Mempertimbangkan dari beberapa faktor di atas didapat tapak seperti pada gambar di bawah ini (lihat Gambar 1. Lokasi Tapak)

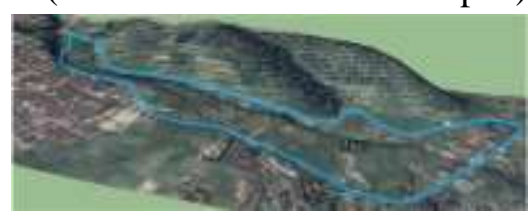

Gambar 1. Lokasi Tapak

\subsection{Analisis Pencapaian}

Tujuan dari analisa ini mendapatkan pencapaian tapak yang baik sesuai dengan fungsi bangunan. Dasar pertimbangan yang digunakan dalam analisa kegiatan ini, yakni sebagai berikut:

\subsubsection{Main Entrance (ME)}

Dasar pertimbangannya adalah mudah dikenali dan mudah dicapai oleh pengunjung, terletak di jalan utama, dan tidak terganggu oleh adanya side entrance.

\subsubsection{Side Entrance (SE)}

Dasar pertimbangannya adalah mudah dalam pencapaiannya, tidak mengganggu kegiatan pengunjung, serta mendukung pola kegiatan service.

\subsection{Analisis Matahari, Angin, Kebisingan, dan Vegetasi}

\subsubsection{Analisis Matahari}

Analisis matahari menghasilkan respon desain seperti pada daerah yang tidak mendapat sinar matahari pagi karena terkendala kontur dapat diatasi dengan adanya jarak bangunan yang proporsi sehingga dapat memanfaatkan sinar matahari pagi secara optimal, serta memberikan bukaan dengan sudut kemiringan tertentu kearah timur mata angin guna mendapat sinar matahari pagi yang bersifat menguntungkan (dapat pula menghangatkan ruang pada waktu pagi hari). Pada analisis matahari ini sangat mempengaruhi dalam respon desain yang dirancang.

\subsubsection{Analisis Angin}

Analisis angin menghasilkan respon desain seperti pada penentuan lokasi perencanaan dan perancangan yang potensial untuk pembangunan. Penggunaan material yang dapat memberi kenyamanan thermal pada pengguna. Dimensi dan jumlah bukaan yang tepat sehingga suhu di dalam ruangan tetap optimal walaupun terjadi penurunan suhu di luar ruangan.

\subsubsection{Analisis Kebisingan}

Analisis kebisingan menghasilkan respon desain terhadap peletakan zona public, semi public, dan zona private.

\subsubsection{Analisis Vegetasi}

Analisis vegetasi menghasilkan respon desain berupa penggunaan pohon pinus, pohon durian, pohon kesemek sebagai filter angin lembah yang bersifat merugikan, serta sebagai penguat tanah guna dan pondasi alami daerah berkontur guna mencegah terjadinya erosi atau tanah longsor. Vegetasi dengan kerapatan maksimum perlu diperhatikan guna dikembangkan, mengingat pentingnya menjaga kondisi ekologis lingkungan.

\subsection{Analisis Kontur}

Kontur pada tapak memiliki kemiringan $10-12^{0}$ dari barat ke timur dan bagian timur yang memiliki kontur paling tinggi (lihat Gambar 2. Potongan Kontur) 



Gambar 2. Potongan Kontur

\subsection{Analisis Sirkulasi}

\subsubsection{Sirkulasi Pejalan Kaki}

Sirkulasi pejalan kaki menggunakan jalan dengan lebar 2-2,5 meter yang terletak di samping kanan dan kirinya sirkulasi kendaraan bermotor dengan menggunakan pengerasan paving dan batu alam yang dimana diharapkan tidak mengurangi daerah penyerapan kawasan tapak.

\subsubsection{Sirkulasi Kendaraan Bermotor \\ Pada sirkulasi kendaraan bermotor ini} menggunakan material yang sama dengan sirkulasi pejalan kaki, hanya saja memiliki jalan dengan lebar 5,5-6 meter, pada ada area ini dapat digunakan sebagai jalan wisata untuk mobil pribadi (kendaraan pribadi), minibus agrowisata, dan mobil pengelola (lihat Gambar 3. Sirkulasi Agrowisata).

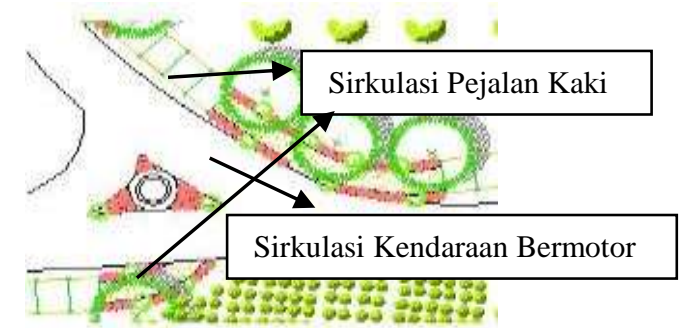

Gambar 3. Sirkulasi Agrowisata

\subsection{Analisis Bentuk dan Tampilan Bangunan dan Kawasan}

Konsep pendekatan kearifan lokal sangat cocok digunakan sebagai konsep pendekatan arsitekturalnya. Agrowisata yang berkearifan lokal mempunyai daya tarik tersendiri bagi wisatawan sebagai daerah kunjungan wisata. Karena kearifan lokal yang diangkat sangat menjunjung tinggi konservasi lingkungan lokus, sehingga di dalam perencanaan dan perancangan Agrowisata Holtikultura Tawangmangu tersebut mengangkat konsep pendekatan yang mampu mengenalkan Tawangmangu sebagai daerah yang menarik sebagai daerah tujuan wisata.

Bentuk dan tampilan bangunan agrowisata tersebut mengadopsi dari bentukbentuk rumah masyarakat sekitar tapak. Sedangkan bentuk dan tampilan kawasan keseluruhan agrowisata mengangkat dari prinsip-prinsip kearifan lokal yang menjadi landasan dalam proses perencanaan dan perancangannya.

Bentuk massa bangunan di dalam Agrowisata Holtikultura Tawangmangu mengadopsi dari bentuk-bentuk bangunan sekitar tapak.

a. Zona Penerima

Pada zona penerima diletakkan massa bangunan yang dapat menjadi point of interest Agrowisata Holtikultura Tawangmangu (lihat Gambar 5. Bangunan Penerima), sehingga menjadi daya tarik sendiri bagi para wisatawan untuk berkunjung. 


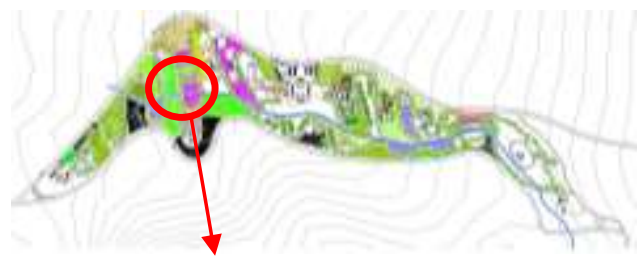

\section{c. Zona Wisata Rekreasi}

Zona wisata rekreasi berisikan bangunan restoran (lihat Gambar 9), SPA (lihat Gambar 10), cottage (lihat Gambar 12), kolam renang (lihat Gambar 11), area bermain, dan ruang terbuka hijau (lihat Gambar 8).

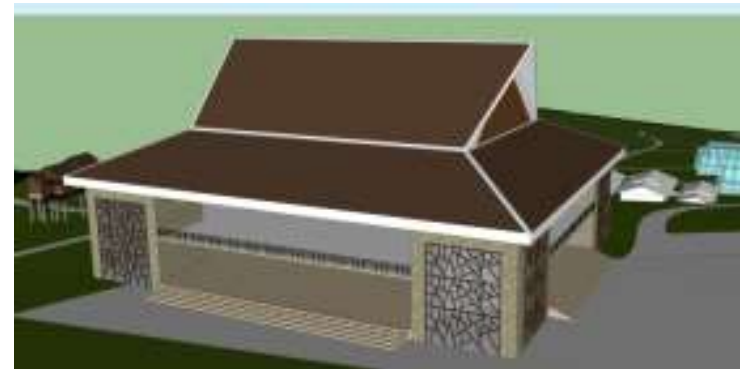

Gambar 5. Bangunan Penerima

\section{b. Zona Wisata Edukasi}

Zona ini merupakan inti dari adanya Agrowisata Holtikultura Tawangmangu yang mempunyai pola kegiatan tanam-petik-jual.


Gambar 6. Bangunan Green House

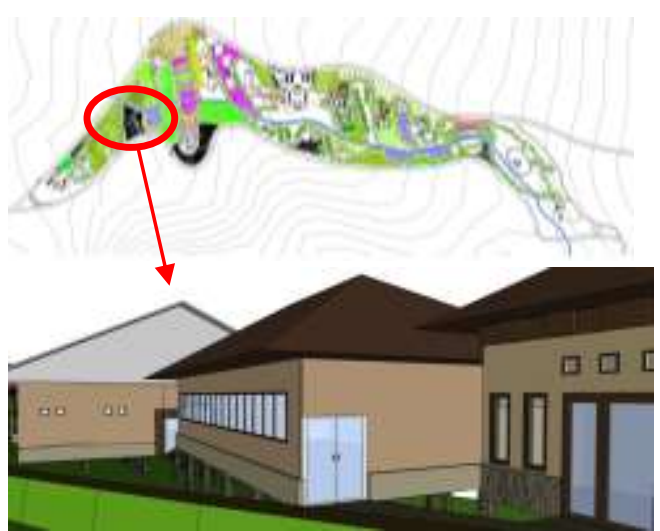

Gambar 7. Bangunan Balai Penelitian dan Perpustakaan

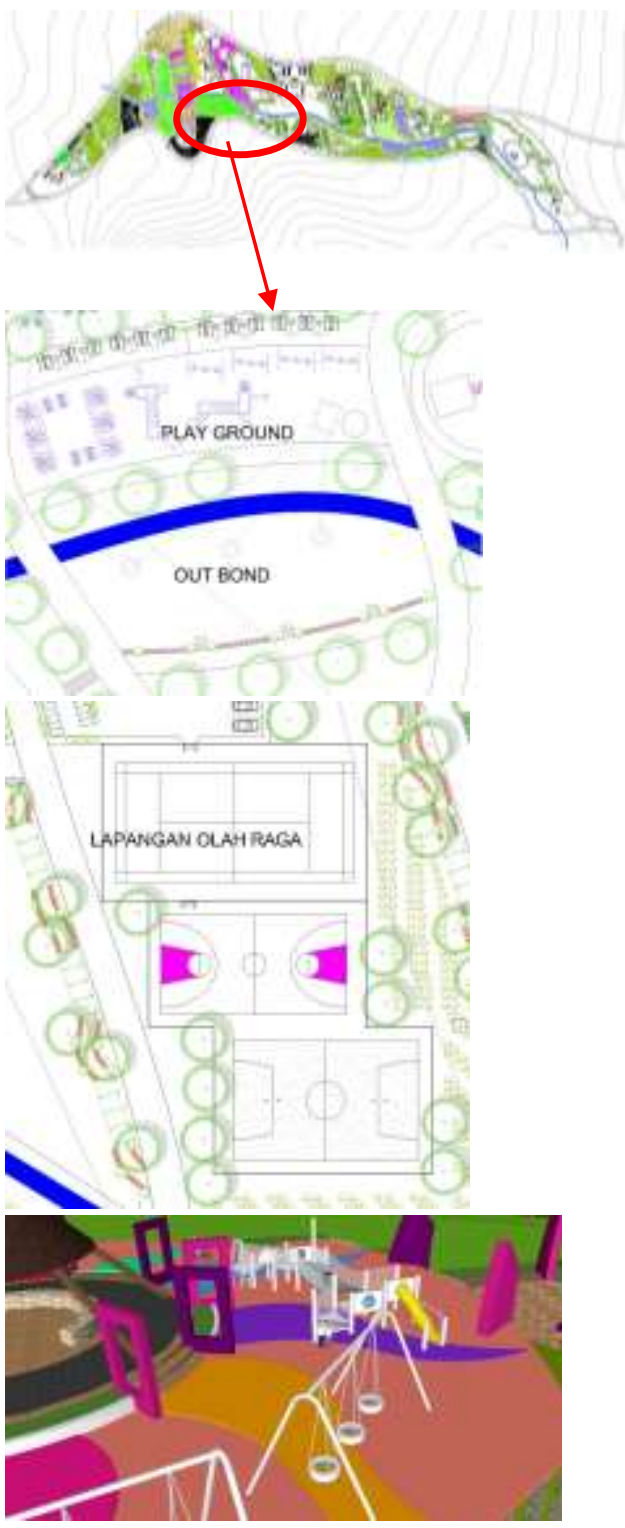

Gambar 8. Area Bermain 

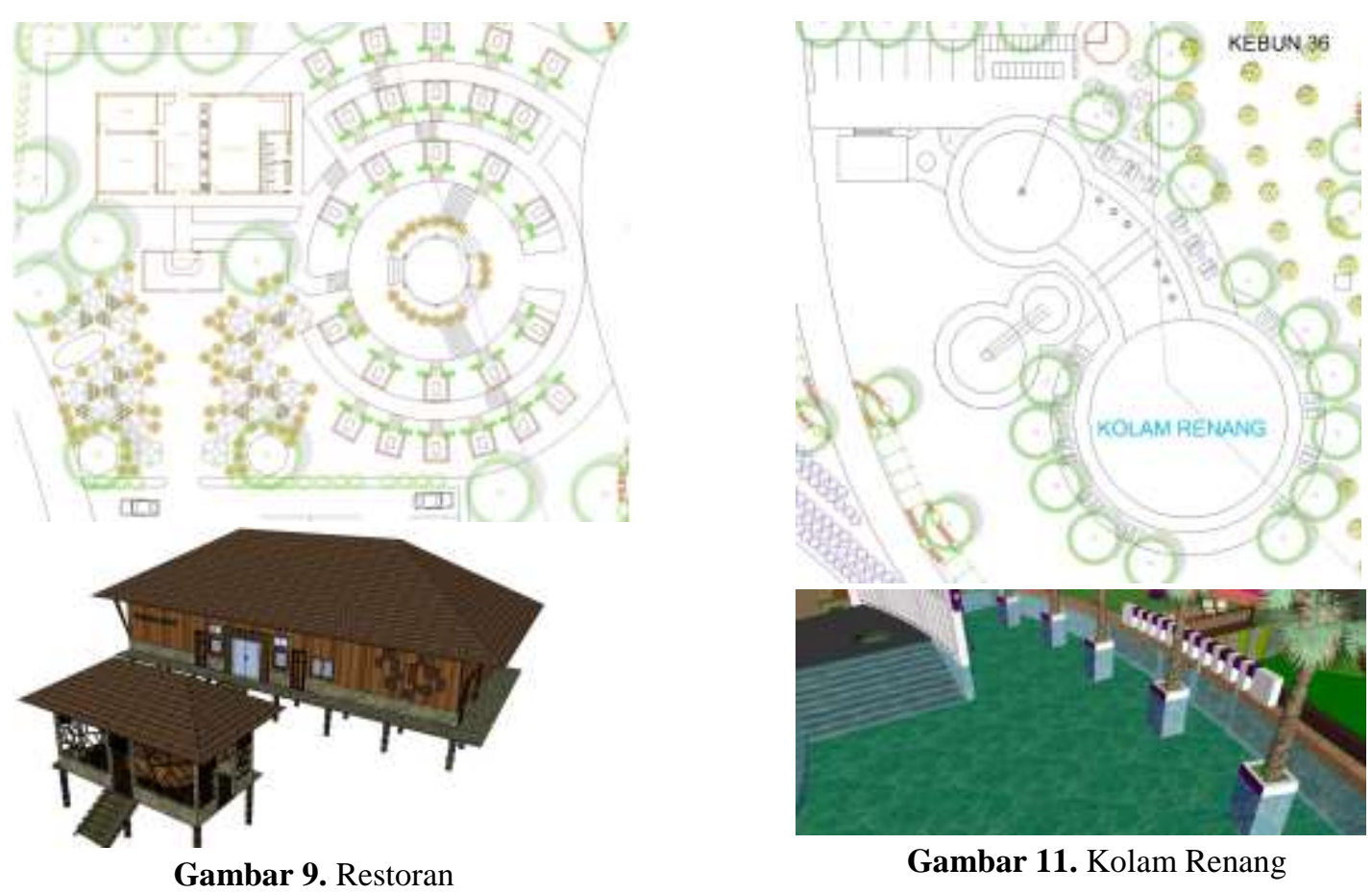

Gambar 11. Kolam Renang

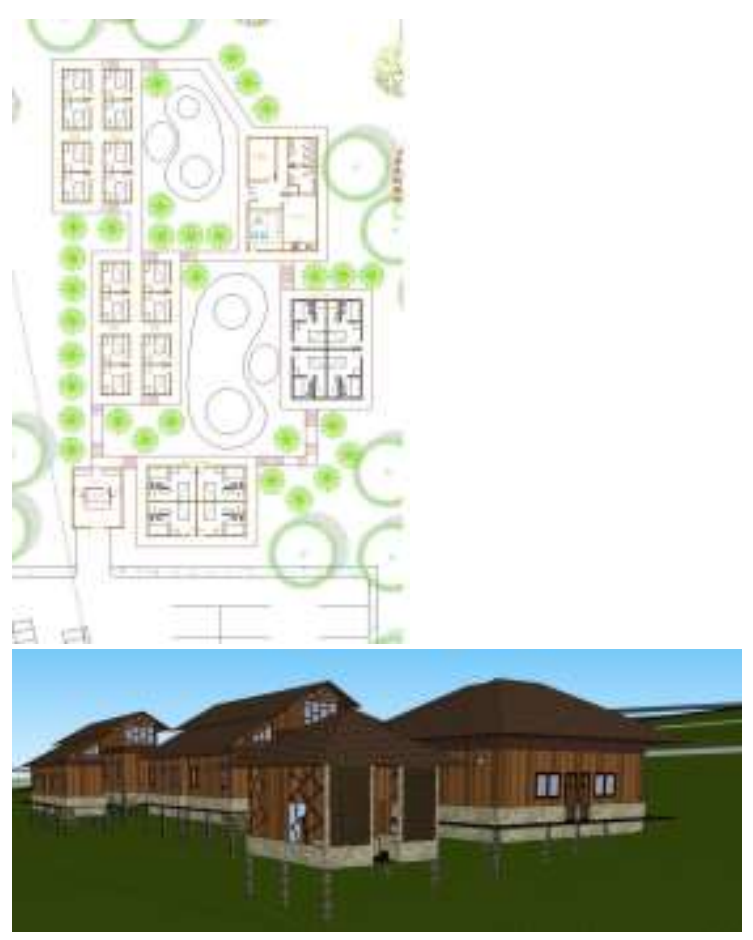

Gambar 10. $S P A$


Gambar 12. Cottage family dan hooneymoon 


\subsection{Konsep Struktur dan Utilitas}

Struktur pada massa bangunan agrowisata tersebut menggunakan struktur bangunan yang standar, sehingga tidak menggunakan jenis struktur yang membutuhkan penjelasan lebih detail. Sedangkan konsep utilitasnya lebih ditekankan pada sistem air bersih dan air kotornya (sistem drainase).

Pada sistem air bersih menggunakan sumber dari mata air pegunungan Lawu yang dialirkan pada pipa-pipa yang ditanam dalam tanah yang kemudian dialirkan pada setiap massa bangunan. Sedangkan pada sistem air kotor, sistem drainasenya menggunakan bebereapa sub bagian, yang pertama menggunakan pipa-pipa kecil yang mengalir di satu pipa yang lebih besar. Kedua, menggunakan main tube yang menjadi tempat muara dari berbagai pipa-pipa saluran air kotor yang kemudian di buang ke sungai yang telah menjadi saluran limbah rumah tangga masyarakat sekitar tapak. Main tube ini memiliki ukuran paling besar dibandingkan dengan pia-pipa saluran air kotor lainnya (sub drainase), sehingga dapat terhindar dari banjir karena adanya konsep utilitas tersebut (lihat Gambar 13).

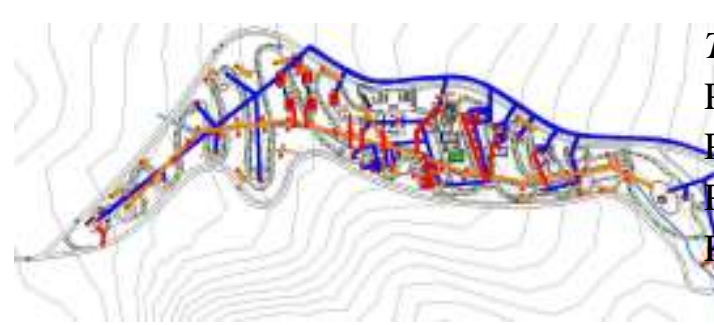

Gambar 13. Drainase Kawasan

\section{KESIMPULAN (KONSEP DESAIN)}

Konsep perencanaan dan

perancangan Agrowisata Holtikultura yang memiliki luas 263.276,67 $\mathrm{m}^{2}$ yang terletak di daerah Tawangmangu Kabupaten Karanganyar dengan pendekatan kearifan lokal ini diharapkan mampu menjadi agrowisata yang menjunjung tinggi nilai-nilai kearifan masyarakat setempat.

Pendekatan kearifan lokal yang diterapkan sangat berguna sebagai landasan rancang bangun kawasan agrowisata yang menjaga kondisi tapak, baik kontur, lingkungan kawasan, dan daerah peresapan kawasan, sehingga menjadi kawasan agrowisata yang meningkatkan konservasi lingkungan, menjaga daerah peresapan, dan menjadi daerah wisata agro yang menonjolkan keadaan tapak yang alami.

Perancangan Agrowisata Holtikultura dengan pendekatan kearifan lokal di daerah Tawangmangu ini juga bertujuan sebagai wadah wisata yang beredukatif mulai dari kegiatan bercocok tanam (tanam), cara pemeliharaan, cara memanen (petik), sampai dengan cara penjualan atau pemasarannya (jual), dan sebagai wadah wisata agro yang rekreatif, sehingga diharapkan Agrowisata Holtikultura di Tawangmangu ini menjadi daya tarik tersendiri bagi wisatawan untuk datang berkunjung.

Dari konsep tersebut yang di mana mencakup pada tema (agrowisata) dan sub tema (kearifan lokal) sehingga menghasilkan rancang bangun Agrowisata Holtikultura di Tawangmangu yang bercirikan atas kearifan lokal.

\section{REFERENSI}

Pitana,I Gede. 2011. Kearifan Lokal Di Tengah Modernisasi. Pusat Penelitian dan Pengembangan Kebudayaan Badan Pengembangan Sumber Daya Kebudayaan dan pariwisata. Kementerian Kebudayaan dan Bariwisata Republik Indonesia 